\title{
Kárpátaljai magyar pedagógusok és tanítványaik metanyelvi ismereteiről
}

\author{
DUDICS LAKATOS KATALIN
}

1. Az elmúlt évtizedekben a magyar nyelvészetben és az anyanyelvoktatás módszertanával foglalkozó szakemberek körében elfogadottá vált a többnormájú szemlélet, amely szerint a standard mellett a nyelv más változatai is egyenrangúak, mindegyiknek megvan a maga funkciója. Ezek a nézetek lassan a közoktatást szabályozó dokumentumokba is beszivárogtak (BEREGSZÁSZI 2014, 2021, PARAPATICS 2020: 66-69), ami jelentős előrelépést jelentett az elmúlt időszakban, figyelembe véve azt a körülményt, hogy az iskolák tehetik a legtöbbet a nyelvekkel, nyelvváltozatokkal kapcsolatos tudományosan megalapozott ismeretek közvetítéséért.

Ennek ellenére több empirikus kutatás is azt igazolta, hogy a ,jó szándék" ellenére a pedagógusok sem tudják könnyen meghaladni azokat a negatív elöítéleteket, amelyek a magyar szubstandard változataival szemben sokukban rögzültek a korábbi középiskolai, felsőoktatási tanulmányaik, illetve mindennapi tevékenységük során (DUDICS LAKATOS 2019: 123-134, JÁNK 2019, PARAPATICS 2020: 69-75). Bár sokszor szándékuk ellenére, mégis olykor hátrányosan különböztetik meg azokat a tanítványaikat, akik iskolai nyelvi megnyilvánulásaik során anyanyelvváltozatukat használják.

A kárpátaljai magyar anyanyelvủek esetében ez az anyanyelvváltozat valamely szláv kölcsönelemekkel tarkított helyi nyelvjárás (GAZDAG 2017, 2019: 47-54, То́тн 2010, 2016: 615-627). Felmérések támasztották alá, hogy kárpátaljai iskolások írásban, nyelvhasználati kérdőív kitöltése közben nagy arányban választottak/produkáltak/fogadtak el standardként a magyar nyelvterületen erösen stigmatizált nyelvi jelenségeket vagy éppen az oroszból/ukránból vett kölcsönszavakat (BEREGSZÁSZI-MÁRKU 2003: 179-207, DudICS LAKATOS 2020: 136-140, LAKATOS 2010). A vizsgálatokból az is kiderült, hogy ennek ellenére elhatárolódnak a nyelvjárásoktól, nyelvjárási beszélőktől, egyfajta régiségként, hagyományként tekintenek ezekre a változatokra. Ugyanez érvényes az őket oktató pedagógusokra is (LAKATOS 2007: 156-163, 2010, 2011: 274-280). 
Egy megismételt kérdőíves kutatás (2008-2018) szerint az anyanyelvoktatási reform óta, a tudományos ismeretterjesztő írások, továbbképzések hatására a kárpátaljai magyar pedagógusok nyelvjárási attitüdje pozitív irányban változott. „A nyelvhasználatra, nyelvváltozatokra vonatkozó kérdőív kitöltése révén nagyobb arányban érkeztek olyan válaszok, melyek a hivatalos tanterv által közvetített hozzáadó szemléletre utalnak, mint 2008-ban. Ennek ellenére a pozitívabb statisztikai adatok kiegészítéseként kapott kifejtett válaszokban érződik még a korábbi szemlélet nyoma: a válaszadók nagy részének nyelvi, nyelvjárási tudata még korántsem nevezhető határozottnak, magabiztosnak. Számos olyan sztereotípia tűnik fel a látszólag jóindulatú, de inkább elnéző írásokban, melyek levetkőzéséhez hosszabb időnek kell eltelnie" (DUDICs LAKATOS 2019: 131).

Feltételezhetően hasonló változás figyelhető meg tanítványaik nyelvjárási attitüdjében is, hiszen a nyelvváltozatokkal kapcsolatban az általuk használt tankönyv korszerü tudományos ismereteket közvetít (BEREGSZÁSZI 2011).

2. 2006 és 2008 között 1490 kárpátaljai magyar iskolás és 150 magyar pedagógus válaszolt nyelvekkel, nyelvjárásokkal kapcsolatos kérdéseimre (LAKATOS 2010). Ezekből az adatokból kiderült, hogy mindkét csoport igyekezett elhatárolódni az alacsony presztízsü nem standard változatoktól, bár rejtett presztízse volt a nyelvjárásoknak körükben: hagyományként, örökségként tekintettek rájuk, többségük azt nyilatkozta, hogy nem beszélnek nyelvjárásban. A nyelvjárások meghatározása kapcsán is többször érkeztek olyan válaszok, amelyek egyértelmủen arra utaltak, hogy sem a pedagógusok, sem tanítványaik nem rendelkeznek hiteles információkkal a magyar köznyelvről, a helyi nyelvváltozatokról. Ismereteik inkább nyelvi mítoszokon alapultak, mint tudományos ismereteken. Az azóta eltelt időszakban viszont a kárpátaljai magyar iskolákban már a hozzáadó szemléletben készült magyar nyelv tanterv szerint tanultak a fiatalok, ${ }^{1}$ s elméletben ezt a szemléletet közvetítették feléjük pedagógusaik is.

Ezek alapján azt feltételezem, hogy a kárpátaljai magyar iskolások, akárcsak pedagógusaik, pozitívabban nyilatkoznak a nyelvjárásokról, bár valószínűleg többségük továbbra sem érzékeli nyelvhasználatának regionális színezetét. Saját szülőföldjük magyar beszédét tartják a legszebbnek. Hipotézisem szerint a kapott válaszokban következetlenség mutatkozik, hiszen a nyelvváltozatokhoz kapcsolódó ismereteik továbbra is hiányosak, felületesek, és sokszor nyelvi mítoszok, nyelvi ideológiák hatása fedezhető fel azokban.

A felmerülő kérdések megválaszolása céljából a korábbi széleskörü vizsgálat megismétléseként két kérdőíves felmérést végeztem el 2018-ban 100 pedagógus és 280 iskolás $^{2}$ részvételével.

\footnotetext{
${ }^{1}$ Az azóta történt változásokról részletesebben lásd BEREGSZÁsZI-Dudics LAKATOS 2019.

${ }^{2}$ Az iskolások körében végzett kutatást a Domus szülőföldi ösztöndíj támogatta.
} 
A pedagógusokat a korábbi kérdőív online változatának segítségével kérdeztem. Ismerős kollégáknak küldtem el, kérve őket, hogy legalább egy-két oktatónak továbbítsák. Az idősebb kollégák a nyomtatott változatot töltötték ki. Öszszesen 100, különböző szakos tanár válaszolt a nyitott és zárt kérdésekre. A tanulók az iskolában, tanórán töltötték ki a kérdöívet. 20 általános és középiskolába mentem el személyesen, vagy juttattam el ismeröseimmel, gyakorlaton lévő tanítványaimmal a kérdéseket. A kérdőív kitöltése 35-40 percet vett igénybe. Az alacsony osztálylétszámok miatt ${ }^{3}$ a 20 intézményben összesen 280 kilencedikes és tizenegyedikes tanuló vett részt a felmérésben.

3. Hasonló felmérések eredményei alapján és gyakorló pedagógusként, főiskolai oktatóként végzett megfigyeléseim szerint fontosnak tartottam megkérdezni adatközlőimet arról, hogy érzékelik-e a magyarországi és más határon túli területek nyelvváltozatai közötti különbségeket, s ha igen, melyiket tartják szebbnek. Ezért feltettem adatközlőimnek a szociolingvisztikai vizsgálatok során gyakori Hol beszélnek a legszebben magyarul? kérdést. A zárt kérdés válaszlehetőségei között szerepelt az összes határon túli magyar és több magyarországi terület. Ez utóbbiakat a következőkben egy csoportban említem Magyarországként. A pedagógusokat arra is megkértem, hogy indokolják döntésüket. Figyelemre méltó a két csoport válaszai között mutatkozó különbség (lásd az 1. ábrát).

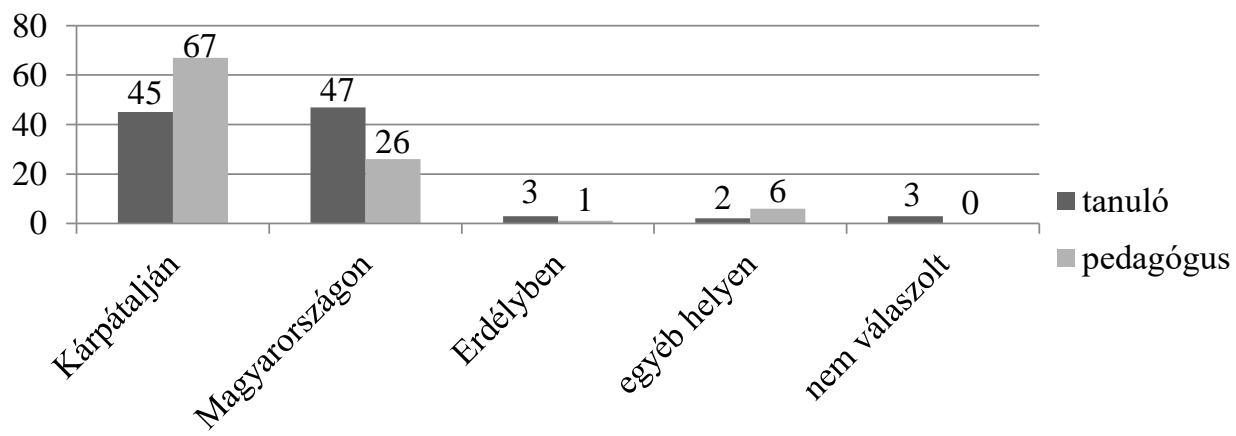

1. ábra. Hol beszélnek a legszebben magyarul? (\%) $\mathrm{N}=280+100$

A fiatalok nagyjából azonos arányban jelölték meg a magyarországi területeket és szülőföldjüket, míg a pedagógusok $67 \%$-a a kárpátaljai magyar beszédet mondta a legszebbnek. Ez a pozitív attitüd igencsak biztatónak tünik, hiszen az érzelmi kötődés erósíti az adott nyelvváltozat presztízsét. Ha viszont az indoklásokat is elolvassuk, láthatjuk, hogy a válaszokat meghatározó vélemények sok esetben olyan nyelvi mítoszokon alapulnak, melyek eloszlatása éppen az

${ }^{3}$ Míg 2006-ban például a Barkaszói Középiskolában 23 érettségi előtt álló fiatal vett részt a felmérésben, 2018-ban csupán 8 ember tanult a végzős osztályban. 
iskola feladata lenne. Az adatközlők körében megmutatkoznak a „tiszta” magyar nyelvröl, a kétnyelvüség negatív értelmü „,kevertségéröl”, a „szleng” igénytelenségéről szóló hiedelmek: mind Kárpátalját, mind pedig Magyarországot érintően feltűnik ez a megítélés a vélemények között.

Azok, akik szerint Magyarországon beszélnek a legszebben magyarul, leginkább a vidéki városokat, falvakat említették: „, Ott még vannak nyelvi változatok, viszont tisztán ejtik a hangokat”, „A városi emberek több helyen fordulnak meg, mint a falusi egyszerü emberek”, „A városokban szebben beszélik a magyar nyelvet, mint a falvakban, vagy Kárpátalján, mert Kárpátalján is és a falvakban is nyelvjárások vannak. Budapestiek viszont már annyira szépen akarnak beszélni, hogy azzal teszik csúnyává”.

Többen indokolták a magyarországi terület megjelölését azzal, hogy negatív ellenpéldaként a kárpátaljai magyar beszédet említették, pontosabban annak kontaktusjelenségeit. Ez kevéssé tetszik az adatközlőknek, hiszen ,igénytelenségre” utal: „Sajnos, Kárpátalján a szláv nyelvi közösség nagyon rányomja a bélyegét a magyar nyelvhasználatra, az igénytelenség abban mutatkozik meg leginkább, hogy az itteni magyar nemzetiségü ember keverék nyelven beszél”, „Szerintem magyarországi kis falvakban beszélnek a legszebben, mert ott nem keveredik az ukránnal, de nem is városias a nyelvhasználatuk”.

Akik szerint Kárpátalján beszélnek legszebben magyarul, többször kiemelték, hogy itt még nem terjedt el a szleng használata. Több olyan fogalom is feltünik ezekben az írásokban, melyek jelentése, tartalma objektív módon nem határolható körül: „A hivatalos nyelvhez véleményem szerint az itt beszélt dialektus áll a legközelebb”, „Tisztán csengö, világos. Formailag és szókincsében a leginkább magyaros”, „A külhoni magyarok vigyáznak nyelvük szépségére, tisztaságára”, „Magyarországon szerintem az emberek többsége már rengeteg idegen szót átvett, szleng szavakat, és használja is a mindennapi beszédében, ami szerintem csorbát ejt a nyelv szépségén”, ,, Szlengmentes, tisztább, kifejezőbb”.

Többen említették azt a kárpátaljaiak körében igencsak elterjedt vélekedést, miszerint a magyarországiak nem ejtik az $o ́$ hangot, helyette $o$-t használnak: „Véleményem szerint a Kárpátalján élö magyar emberek beszélik legszebben a magyar nyelvet, mert mivel mi minden hangot és betüt helyesen ejtünk ki. Én azt tapasztaltam, hogy Magyarországon eltünt az Ó betü, helyette az O betüt ejtik hosszabban, és így lett rövid $O$ és hosszú $O$, nem pedig $O$ ". , ,Véleményem szerint, azért a Kárpátaljai magyarok beszélnek a legszebben mivel mi hangsúlyosan és kifejezöen beszéljük a nyelvünket. Nekem a Magyarországon élök beszédstílusa azért nem tetszik, mivel ők egyes hosszú magánhangzókat rövidnek ejtenek”.

A nyelvjárások is többször szerepelnek az indoklásokban, bár nem mindig egyértelmủ, hogy pozitívumként vagy negatívumként említik, illetve hogy mit értenek nyelvjárás, tájszólás alatt: „Kárpátalján megmaradt a hagyomány a nyelv terén, Kárpátalján nincs tájszólás”, „, Nálunk jelen van az izes magyar és 
a tájnyelv egyaránt”, „Ha nem tájszólásban beszélnek, itt ejtik ki a legszebben a szavakat".

Ezekből az indoklásokból jól látható, hogy a felmérésben részt vevő különböző szakos tanárok (nem laikusok) anyanyelvváltozatukhoz érzelmileg erösen kötődnek ugyan, viszont számos tévhit, tudományos alapot nélkülöző, sokszor ellentmondásos ismeret alapján fogalmazták meg véleményüket.

Mindkét felmérés során megkérdeztem a résztvevőket, mit neveznek nyelvjárásnak: a pedagógusok $85 \%$-a, a tanulók $63,3 \%$-a válaszolt erre a kérdésre.

A pedagógusoktól érkezett olyan meghatározás, amely a területiséget, a változatjelleget emelte ki: „A nyelvjárás olyan nyelvváltozat, ami meghatározott földrajzi területhez kötödik, és hangtani, alaktani, vagy szókészlettani szempontból eltér a köznyelvtöl"; és olyan is, amely csak hagyományként említi: „Egyes vidékek megszokott, régröl örökölt beszédkészsége, ami utódról, utódra száll". Olyan megítélés is előfordul, amely az identitás kifejezésének eszközeként határozza meg a nyelvjárást, viszont a „helyes” beszéddel szembeállítva, s ezzel máris megbélyegezve a helyi kötődését nyelvhasználatával jelző személyt: „Egy adott területre jellemzö kissé a helyes magyar kifejezéstől eltérö beszédstílus, amely sokszor a hovatartozás jele. Tájszólás alapján akár személyek lakhelyét is beazonosithatjuk". Több olyan véleményt is olvashatunk, amelyek dialektológiai ismeretek hiányában egyértelműen negatív elóítéleteket fogalmaznak meg: „Nyelvjárás-nyelvváltozat, ugyan abból a nyelvböl alakul ki, de használata során eltérést mutat attól a nyelvtöl, amelyböl ered”, „Egy elszigetelt vidék lakosságának nyelve”, „Egyes falvak, faluk, saját szavaikkal mássá teszik a falujukat, nem csúnya, de mégis felismerhetö, hogy az már tájszólás, mert eltér a saját magyar nyelvtöl”, „, A szavak furcsa kiejtését, ami egy népcsoportra jellemzö”, „, Mikor egy adott szót, kifejezést különbözöen ejtenek ki, nem a megfelelö betüket használva".

A tanulók meghatározásai előzetes feltevéseimtől eltérően több ponton eltérnek a pedagógusokétól. Olvashatunk olyan megfogalmazást a fiatalok tollából, amely a 11. osztályos Magyar nyelv tankönyv (BEREGSZÁSZI 2011: 43-52) meghatározásának szempontjait idézi: „Nyelvjárás - a nyelvhasználatnak egy meghatározott földrajzi területhez kötödö jellemzö nyelvhasználata.”, ,, a nyelvjárások az irodalmi és a köznyelv egységesitő hatásától viszonylag mentes nyelvváltozatok, amelyeknek önálló rendszerük van”, „A standard magyar nyelvtöl eltérö nyelvváltozat".

Többen voltak olyanok, akik kevésbé szakszerüen, ám sajátjukként határozták meg a fogalmat: , Nyelvjárásnak nevezzük azt, amit a saját falunkban használunk. Amit már gyerekkorunk óta beszélünk.”, „Azt nevezzük nyelvjárásnak, amit a mi falunk és házunkon beszélünk, ami csak arra a helyre jellemzö."

Olyan válaszok is születtek, amelyek a fentiekhez képest hiányosabb metanyelvi ismeretekről vallanak, illetve széles körben elterjedt nyelvi mítoszt 
terjesztenek: „A magyar vagy más nyelvet sajátosabban, parasztiasabban beszélik. Nekem személy szerint nagyon tetszik, kár hogy kihalóban van.”, ,amikor nem tisztán beszélsz valamilyen nyelven".

Összességében azonban a felmérésben részt vevő 280 iskolás — talán meglepő módon — tudományosan megalapozottabb metanyelvi ismeretekről vallott a nyelvjárások meghatározása kapcsán, mint az őket oktató pedagógusok. Ennek magyarázataként meg kell említeni, hogy a válaszadó tanárok között több olyan van, aki utoljára középiskolás korában tanult a magyar nyelvröl, illetve magyar nyelven. Hiszen a magyar szakos vagy alsós tanítók kivételével a II. Rákóczi Ferenc Kárpátaljai Magyar Főiskola létrejötte előtt magyarul nem szerezhettek felsőfokú végzettséget sem a Szovjetunióban, sem Ukrajnában. Jelen tanulmányban ezzel összefüggésben nem végzek elemzéseket, de korábbi vizsgálatok alátámasztották, hogy jóval tudatosabban, pozitívabban nyilatkoznak a nem standard változatokról azok, akik tanulmányaik során dialektológiai vagy szociolingvisztikai ismereteket szereztek (DUDICS LAKATOS 2018, PARAPATICS 2020: 69-75, PRESINSZKY 2011: 241-248, SÁNDOR 2011: 231-239, T. KÁROLYI 2002: 135-144). A kutatásban részt vevő nem magyar szakos pedagógusok tehát legutóbb a homogenizáló, egynormájú, felcserélő anyanyelvoktatási szemlélet szerint szereztek ismereteket a magyar nyelvröl.

Ezzel szemben a 2018-ban 9. és 11. osztályban tanuló fiatalok már a hozzáadó anyanyelvoktatási módszer alapján tanultak anyanyelvükröl: megismerhették nyelvi rendszerét, és az otthonról hozott változattal összehasonlítva ismereteket szerezhettek nyelvváltozatairól, ezek használhatóságról. Megtanulhatták a beszédhelyzethez igazodva kiválasztani az általuk ismert nyelvi kódok közül a megítélésük szerint legmegfelelőbbet. Ezek a viszonylag friss ismeretek valószínüleg befolyásolhatták a fent bemutatott eredményeket. A fiatalok válaszaiból az derül ki, hogy a 10 évvel korábbi adatokkal összehasonlítva pozitívabban, következetesebben nyilatkoznak a nyelvjárásokról, ismereteik megalapozottabbakká váltak. Ezt a 2. ábrán látható arányok is igazolják: míg 2008-ban csupán 27,5\%-uk vallotta magát nyelvjárási beszélőnek, most ez az arány magasabb, mint a pedagógusok esetében.

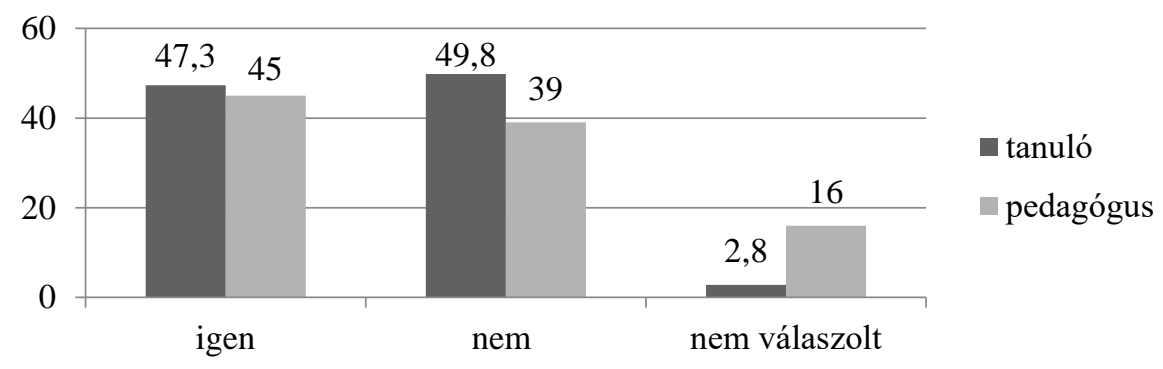

2. ábra. Te/ön beszélsz/beszél valamilyen nyelvjárást? (\%); N=280+100 
4. A fent bemutatott eredmények alapján elmondható, hogy hipotéziseim többsége igazolódott: a kárpátaljai magyar iskolákban a hozzáadó szemlélet eredményeként pozitív változás figyelhető meg a nyelvjárások, nyelvjárási beszélők megítélését tekintve. Mind a pedagógusok, mind tanítványaik nagyobb arányban vallják magukat nyelvjárási beszélőknek. A pedagógusok véleménye (feltételezésem ellenére) tükröződik ugyan tanítványaik megnyilvánulásaiban, viszont a szakemberek nehezebben szakadnak el azoktól az anyanyelvhez kapcsolódó mítoszoktól, amelyek tanulmányaik, pályájuk során sokukban rögzültek. A fiatalabb korosztály, amely az általános iskola 5. osztályától kezdve a hivatalos tantervhez készült tankönyvekben tudományosan megalapozott ismereteket sajátított el, fogékonyabbnak bizonyult a többnormájú, nyitottabb szemléletre. A pedagógusok pedig igyekeztek megfelelni a felmérés során azoknak az elvárásoknak, melyeket megítélésük szerint velük szemben támasztanak. Hiányos metanyelvi ismereteik következtében viszont ez sok esetben a fenti beszámolók és a statisztikai adatok között felfedezhető ellentmondásokhoz, következetlenségekhez vezetett.

Mindezek fényében - a mostani felmérés statisztikáit összehasonlítva a 10 évvel korábbi adatokkal - eredményesnek nevezhető a kárpátaljai anyanyelvoktatási reform. Ezen az úton haladva, következetesen igazodva a hozzáadó szemlélethez, ragaszkodva a tudományos ismeretek közvetítéséhez mind a közoktatásban, mind a felsőoktatásban, a kárpátaljai magyar pedagógusok várhatóan nemcsak szándékuk szerint, hanem a gyakorlatban is elfogadó attitüdöt fognak tanúsítani (ezáltal közvetíteni is) tanítványaik esetleges regionális színezetü nyelvhasználatával kapcsolatban. Az elmúlt években azonban a magyar anyanyelvként való oktatása kényszerü, külső okok következtében Kárpátalján letért a bevált ösvényről (BEREGSZÁSZI-DUDICS LAKATOS 2019: 150-164). Ez pedig mindenképpen kedvezőtlen visszalépést jelent az eredményes anyanyelvoktatás s ezzel együtt a magyar nyelv presztízsének növelése szempontjából.

\section{Irodalom}

BEREGSZÁSZI ANIKÓ 2011. Magyar nyelv 11. osztály. Csernyivci, Bukrek Kiadó.

BEREGSZÁsZI ANIKÓ 2014. Új témák, változó szemlélet. Az anyanyelvi nevelés új irá nya a kárpátaljai magyar középiskolákban. Anyanyelv-pedagógia 1. URL: http:// www.anyanyelv-pedagogia.hu/cikkek.php?id=504 (2020. december 15.).

BEREGSZÁSZI ANIKÓ 2021. Alkalmi mondatok zongorára. A magyar nyelv oktatásának kihívásai kisebbségben. Törökbálint, Termini Egyesület.

BEREGSZÁSZI ANIKÓ-MÁRKU ANITA 2003. A kárpátaljai magyar középiskolások nyelvhasználatáról. In: CSERNICSKÓ IsTVÁN szerk., A mi szavunk járása. Ungvár, PoliPrint. 179-207. 
BERGSZÁSZI ANIKÓ-DUdICS LAKATOS KATALIN 2019. Utak és tévutak az anyanyelvi nevelésben a kárpátaljai magyar középiskolákban. In: CSERNICSKÓ ISTVÁN-MÁRKU ANITA szerk., A nyelvészet mühelyeiböl: Tanulmányok a Hodinka Antal Nyelvészeti Kutatóközpont kutatásaiból 5. Ungvár, Autdor-Shark. 150-164.

DUDICS LAKATOS KATALIN 2018. „...én is nyelvjárásban beszélek”. Anyanyelv-pedagógia 11/2. URL: http://anyanyelv-pedagogia.hu/cikkek.php?id=740 (2020. december 15.).

DUDICS LAKATOS KATALIN 2019. Kárpátaljai magyar pedagógusok nyelvjárási attitüdjének alakulása két felmérés eredményei alapján (2008-2018). Magyar Nyelvjárások 57: 123-134.

DUDICS LAKATOS KATALIN 2020. Efficiency of native language education in Transcarpathia based on a repeated questionnaire survey (2008-2018). Scientific Bulletin of Uzhhorod National University. Series Philology 44: 136-140.

GAZDAG VILMOS 2017. Szláv elemek a kárpátaljai Beregszászi járás magyar nyelvjárásaiban. Doktori disszertáció. Kézirat. Budapest, ELTE BTK.

GAZDAG VILMOS 2019. Ukrán kölcsönszavak a kárpátaljai magyar nyelvhasználati színtereken. In: BALLA, EvELINA-BÁRÁNY, ERZSÉBET-CSONKA, TETYÁNA-GAZDAG, VILMOS-STEFUCA, VIKTÓRIA szerk., Ukrainisztika Magyarországon és a határon túlon / Украӥністика в Угорщинітапозаї̈межами. Nyíregyháza, RIK-U Kiadó. 47-54.

JÁNK IsTVÁN 2019. Nyelvi elöitélet és diszkrimináció a magyartanári értékelésben. Nyitra, Nyitrai Konstantin Filozófus Egyetem Közép-európai Tanulmányok Kara.

LAKATOS KATALIN 2007. Kárpátaljai magyar iskolások és pedagógusok nyelvjárási attitüdjéről. In: GUTMANN MIKLÓS-MOLNÁR ZoLTÁN szerk., V. Dialektológiai Szimpozion. Szombathely, Berzsenyi Dániel Főiskola BTK Magyar Nyelvészeti Tanszék. 156-163.

LAKATOS KATALIN 2010. Kárpátaljai magyar iskolások nyelvi tudata és attitüdje. Doktori értekezés. Kézirat. Budapest, ELTE BTK.

LAKATOS KATALIN 2011. A nyelvjárások megítélése és a nyelvi sztereotípiák összefüggései Kárpátalja magyar iskoláiban. In: HIRES-LÁSZLÓ KORNÉLIA-KARMACSI ZOLTÁN-MÁRKU ANITA szerk., Nyelvi mitoszok, ideológiák, nyelvpolitika és nyelvi emberi jogok Közép-Európában elméletben és gyakorlatban. A 16. Élőnyelvi Konferencia elöadásai. Budapest-Beregszász, Tinta Könyvkiadó-II. Rákóczi Ferenc Kárpátaljai Magyar Főiskola-Hodinka Antal Intézet. 274-280.

PARAPATICS ANDREA 2020. A magyar nyelv regionalitása és a köznevelés. Tények, problémák, javaslatok. Budapest, Tinta Könyvkiadó.

PRESINSZKY KÁROLY 2009. Nyelvi attitüdök vizsgálata nyitrai magyar egyetemisták körében. In: BORBÉLY ANNA-VANČONÉ KREMMER ILDIKÓ-HATTYÁR HELGA szerk., Nyelvideológiák, attitüdök és sztereotípiák. Budapest-Dunaszerdahely-Nyitra, MTA Nyelvtudományi Intézet-Gramma Nyelvi Iroda-Konstantin Filozófus Egyetem Közép-európai Tanulmányok Kar. 241-248.

SÁNDOR ANNA 2009. A nyelvjárási attitűd vizsgálata a nyitrai magyar szakos egyetemisták körében. In: BORBÉLY ANNA-VANČONÉ KREMMER ILDIKÓ-HATTYÁR HELGA 
szerk., Nyelvideológiák, attitüdök és sztereotipiák. Budapest-DunaszerdahelyNyitra, MTA Nyelvtudományi Intézet-Gramma Nyelvi Iroda-Konstantin Filozófus Egyetem Közép-európai Tanulmányok Kar. 231-239.

T. KÁROLYI MARGIT 2002. A nyelvi tudatosság és attitüd vizsgálata a beregszászi föiskola hallgatóinak különbözö csoportjaiban. In: P. LAKATOS ILONA szerk., Mutatványok a hármas határ menti nyelvhasználat kutatásából. Nyíregyháza, Bessenyei Kiadó. 135-144.

TÓTH PÉTER 2010. Kárpátaljai magyar dialektológiai vizsgálatok. Doktori értekezés. Kézirat. Budapest, ELTE BTK.

TÓTH PÉTER 2016. A beregrákosi, nagydobronyi és kajdanói nyelvjárás gyökereiről. In: Czetter Ibolya-Hajba Renáta-Tóth Péter szerk., VI. Dialektológiai Szimpozion. Szombathely-Nyitra, Nyugat-magyarországi Egyetem Savaria Egyetemi Központ-Nyitrai Konstantin Filozófus Egyetem Közép-európai Tanulmányok Kar. 615-627.

\section{On the metalanguage knowledge of Hungarian teachers and their students in Subcarpathia}

Several surveys verified it in the past years that the language dialect attitude of ethnic Hungarian students and teachers in Subcarpathia changed in a positive direction. Despite these developments they still could not entirely discard their negative preconceptions many of them have developed against the non-standard variants of the Hungarian language. In the present study I analyze the data from two questionnaire surveys I conducted in 2018 among students and teachers. From the analysis it becomes clear that the knowledge of the group about language variants is still lacking, resulting in controversies, often inconsistencies which can be observed in their expressions related to language dialects and the ones speaking such dialects.

Keywords: language dialect knowledge, positive attitude, Hungarian students in Subcarpathia, Hungarian teachers in Subcarpathia

Dudics Lakatos Katalin

ORCID: 0000-0003-1354-4421

II. Rákóczi Ferenc Kárpátaljai Magyar Főiskola, Beregszász dudics.katalin@kmf.org.ua 
